\title{
Change in a ferralsol physico-chemical properties under pineapple cropping system in southern of Benin
}

\author{
${ }^{1 * S o s s a ~ E . L, ~}{ }^{1}$ Amadji G.L, ${ }^{2}$ Aholoukpè N.S.H, ${ }^{1}$ Hounsou B.M, ${ }^{1}$ Agbossou K.E, ${ }^{1}$ Hounhouigan \\ D. J. \\ ${ }^{1}$ Faculty of Agronomic Sciences, University of Abomey-Calavi, BP 526 FSA/UAC, Cotonou, Benin. \\ ${ }^{2}$ Agricultural Research Center for Perennial Plants, National Institute of Agricultural Research of Benin, BP \\ 01 Pobe, Benin. \\ *Corresponding author: Elvire Line SOSSA, E- mail: elvas2@yahoo.fr
}

Original submitted in on $15^{\text {h }}$ June 2015. Published online at www.m.elewa.org on $31^{\text {st }}$ July 2015 http://dx.doi.org/10.4314/jab.v91i1.11

\begin{abstract}
Objectives: The study examines the evolution of soil properties under the main pineapple cropping system, in order to evaluate the effectiveness of this system towards maintaining sustainable productivity.

Methodology and Results: The plots of different cropping durations (1.5, 3, 6, 7, 10, 15 and 16 years) were selected from the predominant pineapple cropping system. A fallow plot was identified in a neighbourhood of each selected pineapple plot. Soil profiles were installed in the selected fields and their adjacent fallows to characterize morphological and physico-chemical soil dynamics. The results showed that the values of the morphological and physical characteristics of the soil began to decrease after 10 years of pineapple cropping. The values of chemical characteristics started to decline after 7 years of pineapple cropping.

Conclusions and application of findings: The main pineapple cropping system in the study region improves and maintains the morphological and physical characteristics of the soil up to 10 years of cultivation after which lower values were recorded. In general, the values of the chemical characteristics begin to decline after 7 years of pineapple cropping. It is important to study crop residue management practices that will better manager soil fertility and conservation. For a sustainable use of ferrallitic soils under pineapple, the fertilization system on the plateau of Allada should be strengthened by the addition of organic fertilizers with appropriate crop rotation. This will keep these lateritic soils under pineapple production over a longer period.
\end{abstract}

Keywords: Cropping systems, soil properties, pineapple, Benin.

\section{INTRODUCTION}

Pineapple is one of the most requested tropical fruit on the international market. In West Africa, it is the second most important tropical fruit in terms of production volume, after bananas (FAO, 2009). In Benin, pineapple is the main fruit crop in the south, especially in the Atlantic department. It is grown by about $70 \%$ of farmers whose production represents about $95 \%$ of total production of the country (Helvetas-Benin, 2008). Some authors have identified in Benin a diversity of pineapple cropping systems with various cultural practices likely to influence soil fertility (Agbangba et al., 2008; Agbangba et 
al., 2010; Sossa et al., 2014). They pointed out the use of varying amounts of mineral fertilizers by pineapple producers, who do not follow the recommended fertilizer rates. Agbangba et al. (2008) have mentioned that some Beninese farmers in present conditions of pressure of land use intercrop with pineapple other crops like maize, tomato, cowpea, oil palm, in order to diversify their sources of income. It is recognized by several authors that these practices are likely to affect soil fertility. Moreover, the nearly exclusive use of mineral fertilizers causes soil acidification (Zougmore et al., 2004). The continued use of land causes a decline in soil carbon content, total phosphorus content and in the sum of exchangeable bases; whereas the recycling of crops residues combined with soil tillage techniques and crop rotations improve some soil properties and reduce soil erosion (Wei et al., 2006). The impact of pineapple cropping systems on the changes in soil physical and

\section{MATERIAL AND METHODS}

Study area: The study was carried out on the plateau region of Allada located in the Atlantic department in southern Benin $\left(6^{\circ} 40\right.$ ' $\mathrm{N}$ and $2^{\circ}$ $\left.15^{\prime} 0 \mathrm{E}\right)$. In this area, average rainfall is $1200 \mathrm{~mm}$. The dominant soil type is a low-desaturated lateritic soil, commonly called "terre de barre." This soil has a favourable textural profile with a sandy texture in surface for easy cultivation and over a clayey horizon well structured from about $40 \mathrm{~cm}$ deep, ensuring good water reserve (Azontondé, 1991). The vegetation is a shrubby bush, associated either with more or less dense oil palm chemical properties is not well documented. Tossou (2001) found that pineapple monocropping causes soil and biodiversity degradation. Kintohou (2003) studied the different types of mineral fertilization of pineapple in the town of Allada and showed that NPK fertilizer (10-10-20) is no longer effective. Lui et al. (2013) observed a decrease in soil bulk density, following the use of composted pineapple crop residues. Due to the importance of pineapple crop in Benin and for its sustainable production this study aimed to assess the influence of pineapple cropping systems on soil properties in order to: i) analyze the evolution of the soil physicochemical properties, ii) evaluate the effectiveness of the pineapple cropping system in sustainable maintaining soil productivity and iii) offer to the farmers an additional cultural practices that can improve the performance of this system.

plantation that is found on the plateau naturally or by planting (CeRPA, 2005).

Plots selection and soil study: The farmer's plots were selected in the predominant pineapple cropping system identified by Sossa et al. (2014) in Allada. This pineapple system practiced by $49 \%$ of producers is characterized by the absence of rotation and intercropping, the non-use of organic manure, the recycling of crop residues and by large areas. The plots have been used for a long time by pineapple crop, with a mean of $5.3 \pm 2.5$ years of cropping (Table 1).

Table 1: Characteristics of the dominant pineapple cropping system on the plateau of Allada (Sossa et al., 2014)

\begin{tabular}{ll}
\hline & Cropping system characteristics \\
\hline Rotation & no \\
Crops association & no \\
Organic manure use & no \\
Recycling of crop residue & yes \\
Cultivated area (ha) & $1.0 \pm 0,8$ \\
Mean land use duration (years) & $5.3 \pm 2,5$ \\
Maximum land use duration & 16 years \\
Urea (Kg/ha) & $281.2 \pm 128.0$ \\
$\mathrm{TSP}(\mathrm{Kg} / \mathrm{ha})$ & $49.1 \pm 78.7$ \\
$\mathrm{~K}_{2} \mathrm{SO}_{4}(\mathrm{Kg} / \mathrm{ha})$ & $1.7 \pm 17.7$ \\
$\mathrm{NPK}(\mathrm{Kg} / \mathrm{ha})$ & $414.8 \pm 183.7$ \\
\hline
\end{tabular}


The choice of the plots was based on a chronosequence of land use duration under pineapple crop. Seven land use durations were identified: $1.5 ; 3 ; 6 ; 7 ; 10 ; 15$ and 16 years (Sossa et al., 2014). For each period of land use, three plots were selected. A fallow plot (used as control) was identified in a neighbourhood of each selected pineapple plot. Each associate fallow age was equal to the use duration of the soil under pineapple cultivation. A soil profile for one meter depth was installed in each selected plot and in the adjacent fallow. Each profile has been described by the identification of different soil horizons and by soil morphological characterization. A soil sampling was performed in each soil layer with a knife until $60 \mathrm{~cm}$ depth (rooting depth of pineapple). The soil samples were air-dried for determination of soil parameters in laboratory. Nitrogen $(\mathrm{N})$ was determined by the Kjeldahl method (Kjeldahl, 1883), available phosphorus $(P)$ by Bray-1 method (Bray and Kurtz, 1945), carbon (C) by Bell method (Bell, 1964), the exchangeable cations (K, Ca, Mg)

\section{RESULTS}

Changes in the soil morphological characteristics over the land use duration: The morphological characteristics of soil profile varied depending on the land use duration. The number of soil horizons varies between 3 and 4 according to the land use duration. Soil profile showed an A0 surface organic horizon between 3 and 10 years of soil using under pineapple cultivation. The thickness of this horizon A0 decreases of $46.7 \%$ from 1.5 to 10 years cropping. Similarly, the thickness of all the horizons A declines of $10 \%$ from 1.5 to 16 years cropping (Table 2). by Helmke and Sparks's method (Helmke and Sparks, 1996), cationic exchange capacity by the Metson method (Metson, 1956), the pH by the potentiometric method (in a soil / water ratio of 1 / 2.5) (Jackson, 1968) and soil particles size by the international method, modified by the use of pipette Robinson (Robinson, 1949). A soil sampling with the density cylinder of 100-cm3 volume was made three times in each soil layer for the determination of bulk density. The soil properties for each soil layer were used to calculate the mean value of each parameter for the $0-60 \mathrm{~cm}$ soil layer.

Statistical analyses: A Student t-test was performed on the soil parameters values in order to compare the pineapple plots and the fallow plots relative to the same duration of land use. A principal component analysis was performed using $R$ software (version 3.2.0, 2015) on the soil physico-chemical parameters, in order to evaluate the influence of land use duration on the soil fertility.

Dynamics of soil physico-chemical characteristics: The comparison test of means performed on the bulk density data and total porosity of the soil in fallow and cultivated plots indicated that the soil bulk density of the cultivated plots is higher (3.2 to $23 \%$ ) than the bulk density of the fallow land at each land use duration. A significant difference was observed at 3 years of land use duration. The soil porosity took evidently the opposite trend and is higher on the fallow (1.8 to $11.8 \%$ ) than the cultivated plots (Table 3 ) 
Tableau 2: Soil morphological characteristics

\begin{tabular}{|c|c|c|c|}
\hline \multirow{2}{*}{ Duration (years) } & \multicolumn{3}{|c|}{ Profile characteristics } \\
\hline & Horizons numbers & Horizons types & Average thickness (cm) \\
\hline \multirow{3}{*}{1.5} & \multirow{3}{*}{3} & $\mathrm{~A}$ & 20 \\
\hline & & $A B$ & 22 \\
\hline & & $B$ & $\geq 42$ \\
\hline & \multirow{4}{*}{4} & $\mathrm{~A} \mathrm{O}^{-}$ & 15 \\
\hline \multirow{3}{*}{3} & & A1 & 23 \\
\hline & & $A B$ & 22 \\
\hline & & $B$ & $\geq 60$ \\
\hline \multirow{3}{*}{6} & \multirow{3}{*}{3} & $\mathrm{AO}$ & 10 \\
\hline & & $\mathrm{A} 1$ & 20 \\
\hline & & B & $\geq 30$ \\
\hline \multirow{4}{*}{7} & \multirow{4}{*}{4} & $\mathrm{AO}$ & 12 \\
\hline & & $\mathrm{A} 1$ & 15 \\
\hline & & $A B$ & 26 \\
\hline & & $\mathrm{B}$ & $\geq 53$ \\
\hline & \multirow{3}{*}{3} & $\mathrm{AO}$ & 8 \\
\hline \multirow[t]{2}{*}{10} & & $\mathrm{~A} 1$ & 24 \\
\hline & & B & $\geq 32$ \\
\hline \multirow{3}{*}{15} & \multirow{3}{*}{3} & $A$ & 27 \\
\hline & & $A B$ & 18 \\
\hline & & B & $\geq 45$ \\
\hline & \multirow{3}{*}{3} & $A$ & 18 \\
\hline \multirow[t]{2}{*}{16} & & $A B$ & 18 \\
\hline & & $\mathrm{B}$ & $\geq 36$ \\
\hline
\end{tabular}


Table 3: Variation of physico-chemical characteristics of soil following land use duration

\begin{tabular}{|c|c|c|c|c|c|c|c|c|c|c|}
\hline $\begin{array}{ll}\text { Land } & \text { use } \\
\text { duration (years) }\end{array}$ & $\begin{array}{l}\text { Land } \\
\text { use }\end{array}$ & $\begin{array}{c}\text { Bulk } \\
\text { density }\end{array}$ & $\begin{array}{c}\text { Total } \\
\text { porosity }(\%) \\
\end{array}$ & $\mathrm{pH}$ & $C(\mathrm{~g} / \mathrm{kg})$ & $\mathrm{N}(\%)$ & $\mathrm{C} / \mathrm{N}$ & $P(p p m)$ & $\begin{array}{c}\mathrm{K} \\
(\mathrm{meq} / 100 \mathrm{~g})\end{array}$ & $\begin{array}{c}\text { CEC } \\
\text { (cmol.kg-1) }\end{array}$ \\
\hline \multirow[t]{2}{*}{1.5} & Field & $1.57 \pm 0.09 \mathrm{a}$ & $36.91 \pm 1.28 b$ & $4,92 \pm 0,05 a$ & $3.1 \pm 0.01 \mathrm{~b}$ & $0.1 \pm 0.01 \mathrm{a}$ & $2.773 \pm 0.1 \mathrm{~b}$ & $23.18 \pm 0.12 b$ & $0.61 \pm 0.02 \mathrm{a}$ & $35,99 \pm 1,39 a$ \\
\hline & Fallow & $1.47 \pm 0.1 \mathrm{a}$ & $40.96 \pm 0.06 a$ & $5,1 \pm 0,04 a$ & $6.8 \pm 0.04 \mathrm{a}$ & $0.12 \pm 0.005 a$ & $7.697 \pm 0.43 \mathrm{a}$ & $26.2 \pm 015 a$ & $0.67 \pm 0.03 a$ & $36.03 \pm 1.38 \mathrm{a}$ \\
\hline \multirow[t]{2}{*}{3} & Field & $1.61 \pm 0.01 \mathrm{a}$ & $37.47 \pm 0.66 b$ & $4.9 \pm 0.75 a$ & $5.2 \pm 0.03 \mathrm{a}$ & $0.13 \pm 0.005 a$ & $4.20 \pm 0.14 \mathrm{a}$ & $27.37 \pm 0.09 a$ & $0.55 \pm 0.63 a$ & $20.65 \pm 0.92 a$ \\
\hline & Fallow & $1.52 \pm 0.01 \mathrm{~b}$ & $41.9 \pm 0.13 a$ & $5.87 \pm 0.14 \mathrm{a}$ & $4.5 \pm 0.002 \mathrm{a}$ & $0.1 \pm 0.004 \mathrm{~b}$ & $5.5 \pm 0.69 \mathrm{a}$ & $25.92 \pm 0.02 b$ & $0.76 \pm 0.003 a$ & $21.5 \pm 0.7 \mathrm{a}$ \\
\hline \multirow[t]{2}{*}{6} & Field & $1.48 \pm 0.11 a$ & $38.98 \pm 0.03 b$ & $5.28 \pm 0.01 \mathrm{~b}$ & $13.7 \pm 0.04 \mathrm{a}$ & $0.06 \pm 0.002 \mathrm{a}$ & $19.59 \pm 0.84 \mathrm{a}$ & $19.76 \pm 0.34 b$ & $0.57 \pm 0.002 b$ & $33.56 \pm 0.79 b$ \\
\hline & Fallow & $1.39 \pm 0.12 \mathrm{a}$ & $42.97 \pm 0.04 a$ & $5.65 \pm 0.05 a$ & $9.8 \pm 0.03 b$ & $0.09 \pm 0.01 \mathrm{a}$ & $17.5 \pm 0.71 \mathrm{a}$ & $35.64 \pm 0.19 a$ & $1.12 \pm 0.004 \mathrm{a}$ & $38.5 \pm 0.71 \mathrm{a}$ \\
\hline \multirow[t]{2}{*}{7} & Field & $1.51 \pm 0.13 a$ & $44.41 \pm 0.58 a$ & $5.68 \pm 0.26 \mathrm{a}$ & $11.9 \pm 0.02 \mathrm{a}$ & $0.1 \pm 0.006 \mathrm{~b}$ & $12.97 \pm 0.04 b$ & $23.46 \pm 0.09 a$ & $0.66 \pm 0.006 b$ & $25.61 \pm 0.86 b$ \\
\hline & Fallow & $1.45 \pm 0.07 \mathrm{a}$ & $42.74 \pm 0.37 a$ & $5.76 \pm 0.18 \mathrm{a}$ & $5.1 \pm 0.02 b$ & $0.14 \pm 0.005 a$ & $16.5 \pm 0.71 \mathrm{a}$ & $12.13 \pm 0.05 b$ & $1.07 \pm 0.04 \mathrm{a}$ & $29.83 \pm 0.24 \mathrm{a}$ \\
\hline \multirow[t]{2}{*}{10} & Field & $1.61 \pm 0.12 \mathrm{a}$ & $40.93 \pm 0.1 \mathrm{a}$ & $5.48 \pm 0.41 a$ & $15 \pm 0.71 \mathrm{a}$ & $0.14 \pm 0.0005 a$ & $7.77 \pm 0.32 \mathrm{a}$ & $22 \pm 0.002 a$ & $1.75 \pm 0.001 \mathrm{a}$ & $31.19 \pm 1.69 b$ \\
\hline & Fallow & $1.56 \pm 0.05 a$ & $41.68 \pm 0.44 a$ & $5.94 \pm 0.08 \mathrm{a}$ & $6.2 \pm 0.005 a$ & $0.13 \pm 0.0001 \mathrm{a}$ & $16.5 \pm 3.54 \mathrm{a}$ & $13.14 \pm 0.06 b$ & $1.6 \pm 0.003 b$ & $39.5 \pm 0.71 \mathrm{a}$ \\
\hline \multirow[t]{2}{*}{15} & Field & $1.71 \pm 0.13 a$ & $37.78 \pm 0.31 b$ & $5.47 \pm 0.12 \mathrm{a}$ & $7.5 \pm 0.01 \mathrm{a}$ & $0.122 \pm 0.004 \mathrm{a}$ & $5.63 \pm 0.89 a$ & $9.59 \pm 0.019 b$ & $1.02 \pm 0.004 b$ & $31.07 \pm 0.1 \mathrm{a}$ \\
\hline & Fallow & $1.39 \pm 0.26 \mathrm{a}$ & $39.85 \pm 0.21 \mathrm{a}$ & $5.81 \pm 0.26 \mathrm{a}$ & $5.3 \pm 0.004 \mathrm{~b}$ & $0.121 \pm 0.001 \mathrm{a}$ & $8.5 \pm 0.71 \mathrm{a}$ & $19.33 \pm 0.18 a$ & $1.1 \pm 0.001 \mathrm{a}$ & $31 \pm 2.83 \mathrm{a}$ \\
\hline \multirow[t]{2}{*}{16} & Field & $1.6 \pm 0.14 \mathrm{a}$ & $\begin{array}{c}42.569 \pm 0.61 \\
b\end{array}$ & $5.44 \pm 0.46 \mathrm{a}$ & $8.9 \pm 0.01 \mathrm{a}$ & $0.13 \pm 0.0001 \mathrm{a}$ & $5.5 \pm 0.71 b$ & $20.57 \pm 0.1 b$ & $1.3 \pm 0.01 b$ & $30.71 \pm 1.0 \mathrm{~b}$ \\
\hline & Fallow & $1.35 \pm 0.1 \mathrm{a}$ & $46.47 \pm 0.75 \mathrm{a}$ & $6.353 \pm 0.63 a$ & $6.1 \pm 0.004 b$ & $0.13 \pm 0.001 a$ & $19.5 \pm 0.71 \mathrm{a}$ & $\begin{array}{c}33.29 \pm 0.006 \\
a\end{array}$ & $1.5 \pm 0.02$ & $36.5 \pm 0.71 \mathrm{a}$ \\
\hline
\end{tabular}


The principal component analysis performed on the soil physical characteristics of the soilcultivated plots for the different duration, reveals that the first two axes alone account for $92.7 \%$ of the total variance, which is sufficient to ensure proper interpretation. The total porosity and clay content are positively correlated with axis 1 ; while sand content, bulk density and available water are negatively correlated to it (Figure 1). The silt content is positively correlated to axis 2 . Unlike the sand content, the bulk density and the available water soil, the total porosity and the clay content increase with duration of land use to 10 years of cropping, and fall beyond this land use duration. The clay content of the soil continuously increases with land use duration (Figure 1). Soil parameters values in the fallow and cultivated plots are presented in the table 3 . The values of $\mathrm{pH}, \mathrm{C} / \mathrm{N}$ ratio, $\mathrm{K}$ and $\mathrm{CEC}$ are lower on the cultivated plots than on the fallow land at each land use duration. We note significant differences at 6 years of land use for $\mathrm{pH}$; at 1.5, 7 and 16 years land use for $\mathrm{C} / \mathrm{N}$; at 6 and 16 years land use for $K$; at $6,7,10$ and 16 years of land use for CEC. The soil phosphorus content is significantly higher on the plots under fallows than on the cultivated fields for the land use durations 1.5, 15 and 16 years. On the other hand, it is higher in cultivated fields for others durations of land use. The carbon content is globally lower on plots under fallows than on the cultivated fields, excepted for the 1.5-years land use. This decline varied with time; it is of $13.5 \%, 28.5 \%, 57.1 \%$, $58.7 \%, 29.3 \%$ and $31.5 \%$ respectively for land use durations $3,7,10,15$ and 16 years (table3).

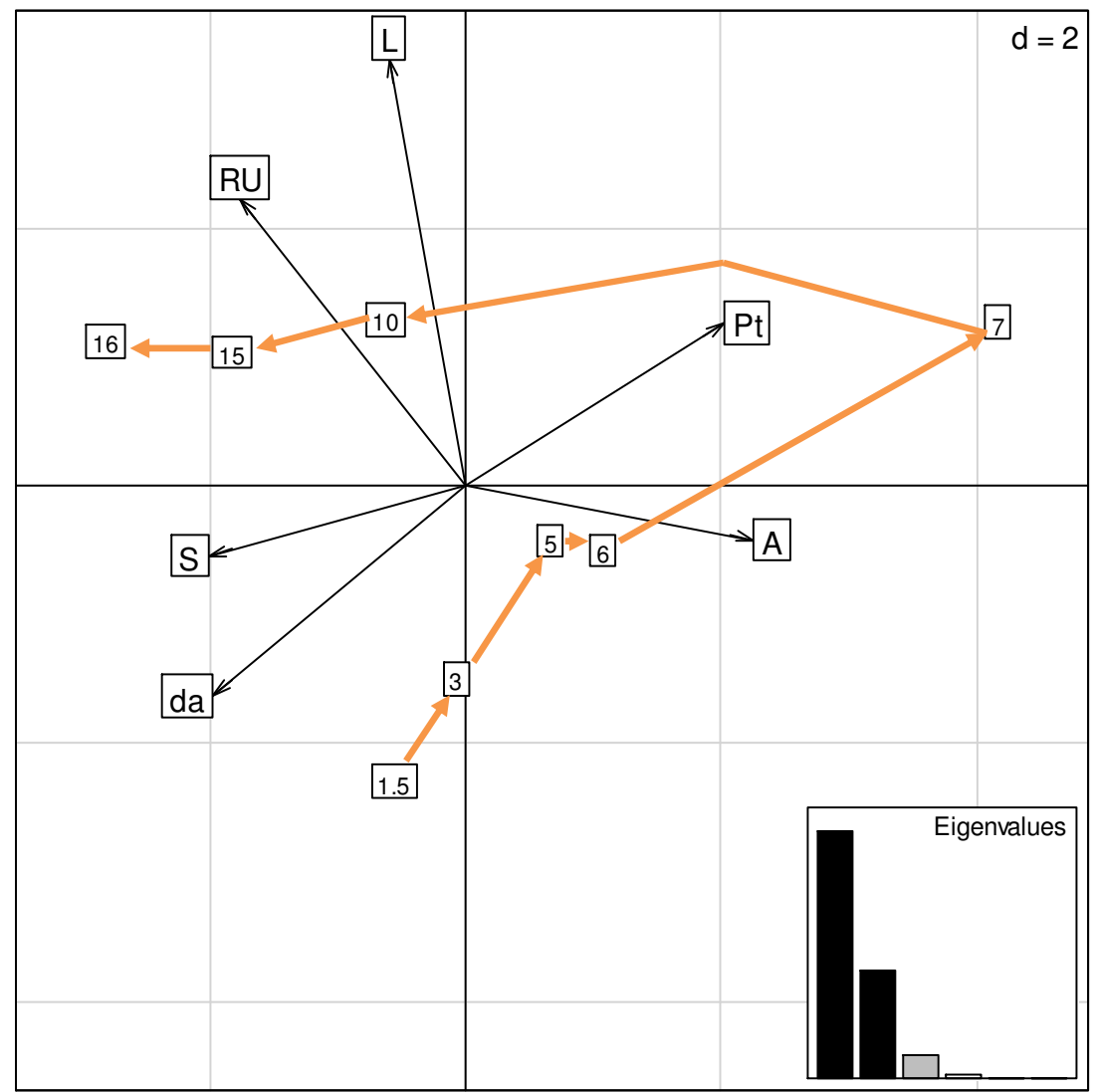

Figure 1: Projection of soil physical properties in the factorial plan (Axis2, Axis1) of the PCA showing the dynamic following land use duration

$\mathrm{Pt}=$ Total porosity, $\mathrm{A}=$ =Clay, $\mathrm{L}=\mathrm{Silt}, \mathrm{S}=$ sand, $\mathrm{da}=$ Bulk density, $\mathrm{RU}=$ available soil water

The positioning of chemical properties of cultivated soil in plane axes of the principal components analysis (figure 2) showed that the first two components explain $71.44 \%$ of the total variance. Potassium levels and $\mathrm{pH}$ are negatively correlated to axis 1 ; while phosphorus, magnesium and CEC are positively correlated to that axis. On the axis 2 , carbon and calcium, and $\mathrm{C} / \mathrm{N}$ ratio are negatively correlated, while the nitrogen is positively correlated. 


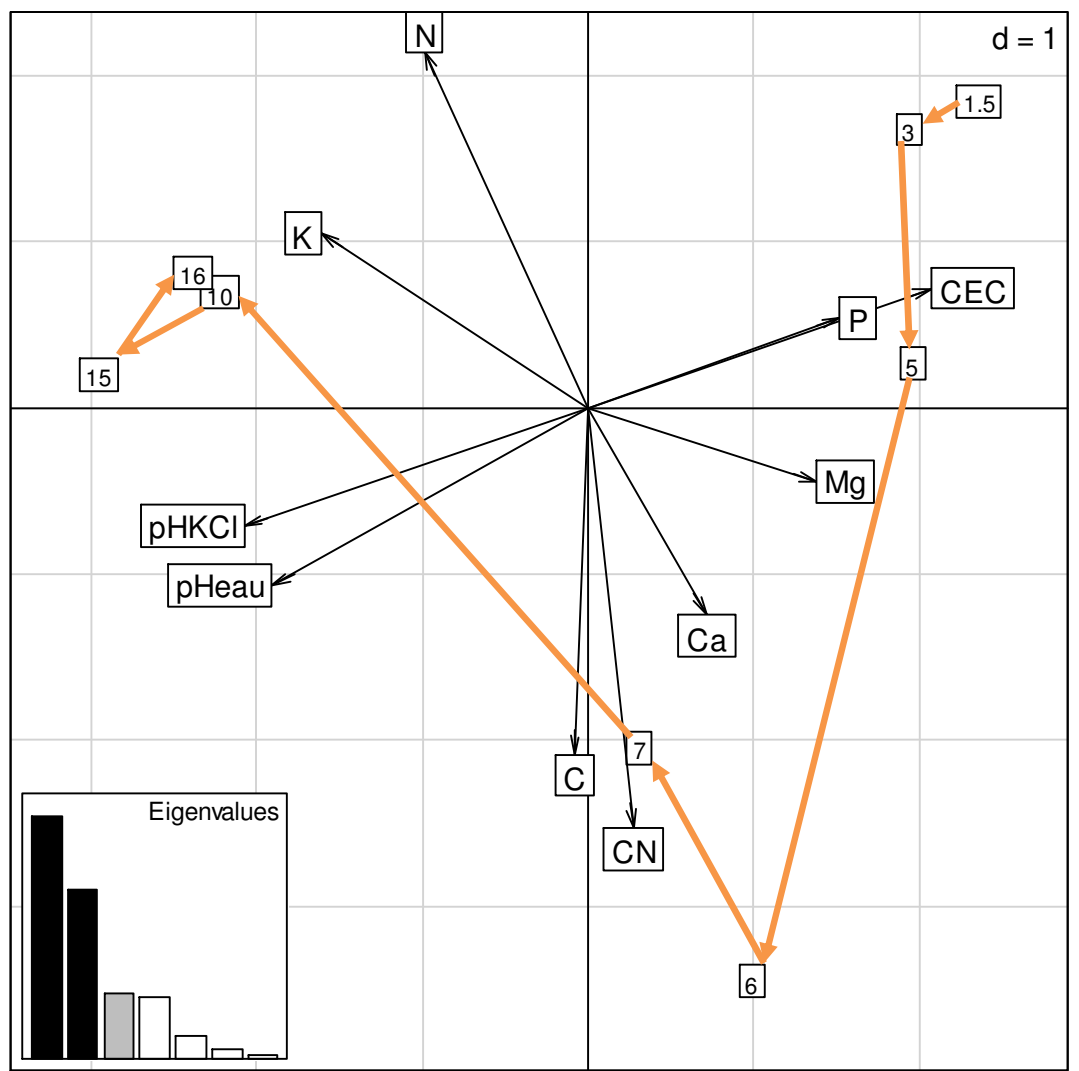

Figure 2: Projection of soil chemical properties in the factorial plan (Axis2, Axis1) of the PCA showing the dynamic following land use duration

The cultivated soil during periods of less than or equal to 7 years, have higher CEC, phosphorus and magnesium levels but lower $\mathrm{pH}$ and lower potassium levels. Land use beyond 7 years leads to a decrease in CEC, phosphorus and magnesium contents; but an increase in potassium and $\mathrm{pH}$. In

\section{DISCUSSION}

The study of the characteristics of lateritic soils under the prevailing pineapple cropping system on the plateau of Allada revealed that soil morphological and physico-chemical properties varied according to land use duration. This system is characterized by the absence of rotation, intercropping and non-application of organic manure and by the recycling of crop residues and large areas (Sossa et al., 2015). It modifies the soil morphological and physico-chemical characteristic according to the land use duration up to 16 years. The recycling of crop residues is certainly the practice that justifies the effectiveness of this system. Indeed, Lui et al. (2013) noted a decrease in soil bulk density, following the use of composted pineapple crop residues. The decline in soil bulk contrast to nitrogen content, $\mathrm{C} / \mathrm{N}$, carbon and calcium in the soil increase with the duration of land use up to 7 years under the prevailing system. After this period, a decrease of $\mathrm{C} / \mathrm{N}$, carbon and calcium soil associated with an increase in soil nitrogen content was observed.

density, due to the use of crop residues has also been demonstrated by several authors (Edwards et al. 2000; Abdelhamid et al., 2004; Evanylo et al., 2008). The decomposition of crop residues while increasing the carbon content and the total porosity of the soil, causing the decline in soil bulk density (Shaver et al., 2003), making soil looser, with consistent aggregates and well individualized (Yemefack et al., 2004). According to Hien et al. (2002), inputs of organic compounds in the form of aerial and root litter participate in rebuilding of the soil organic matter. This justifies the presence of the organic surface horizon $\mathrm{A} 0$ in the soil profile of our study plots. The increase of silt and clay contents, and the decrease of sand contents between 1.5 and 10 years cropping would be 
linked to the use of crop residues. Indeed, soil macrofauna is enriched by the incorporation of crop residues (Mamoudou et al., 2012). The activity of soil organisms including termites and soil-ingesting worms is likely to go up from the subsurface horizons, the fine soil surface particles (clay and silt) reducing the proportion of sand in the first horizons (Yemefack, 2004; Alongo, 2013). The practice of continued pineapple monoculture and exclusive incorporation of crop residues in the dominant system of pineapple cultivation could justify the revival of the proportion of sand in the upper soil horizons beyond 10 years, made of the gradual decline of the richness and the diversity of soil macrofauna. According to Parmelee et al. (1990) and Decaëns et al. (1994), soil macrofauna should be maintained particularly through the association or rotation with legumes and the reduction of tillage frequency. The incorporation of the crop residues into the soil, also increases soil content in N, P, K and enhances its exchangeable cations (Kowaljow and Mazzarino, 2007; Courtney and Mullen, 2008; Sommer et al., 2011;. Lui et al., 2013). This practice also allows reducing the need for mineral fertilizers (Chikae et al., 2006; Gabhane et al., 2012.). In the studied system, the mean levels of carbon, calcium, phosphorus, magnesium and soil CEC began to decline, for land durations

\section{CONCLUSION}

This study revealed that the soil properties varied according to the land use duration. The dominant pineapple crop system, mainly characterized by the return of crop residues, contributes to the maintenance of morphological and physicochemical characteristics of soil, up to 10 years. Beyond this period, soil fertility decrease. It is important to study crop residue management beyond 7 years. Even after 10 years of cultivation, bulk density and sand rates rose. This shows that the decline of soil fertility under this system starts after 7 years of use. However, the decrease in the phosphorus content in the soil could not affect significantly the production of pineapple because Godfrey et al. (1971) reported that phosphorus requirements of pineapple are limited. In addition, the optimum $\mathrm{pH}$ for the cultivation of pineapple is between 4.5 and 5.5 (Py et al., 1965). On all land use studied durations, a change in $\mathrm{pH}$ from 4.9 to 5.5 is suitable for pineapple cropping. The optimum $\mathrm{pH}$ appears linked to the availability of trace elements in the soil (Py et al., 1965). Mineralization of nitrogen from organic inputs is often limited to short and its accumulation becomes noticeable after 5 years of cropping (Blackshaw et al., 2005; Barbarick and Ippolito, 2007; Leroy et al, 2007). The regular input of organic matter in the soil, through compost or manure, improves its contents of $\mathrm{C}$ and $\mathrm{N}$ and led to over 10 years in the accumulation of nitrogen in the soil, indicating physical protection of this nutrient in macroaggregates (Whalen and Chang, 2002; Meng et al, 2005; Mallory and Griffin, 2007; Sodhi et al., 2009). This organic matter is well degraded as underline globally the $\mathrm{C} / \mathrm{N}$ values of the cultivated plots.

practices that will better manage soil fertility and conservation. For a sustainable use of ferrallitic soils under pineapple, the fertilization system on the plateau of Allada should be strengthened by the addition of organic fertilizers with appropriate crop rotation. This will keep these lateritic soils under pineapple production over a longer period.

\section{ACKNOWLEDGMENT}

The authors thank the Competitive Fund Program for Researches of Abomey-Calavi University (PFCR/UAC) for its material and financial support.

\section{REFERENCES}

Abdelhamid MT, Horiuchi T, Oba S, 2004. Composting of rice straw with oilseed rape cake and poultry manure and its effects on faba bean (Vicia faba L.) growth and soil properties. Bioresource Technology 93: 183-189.

Agbangba CE, Dagbenonbakin DG, Kindomihou V, 2010. Etablissement des normes du système intégré de diagnostic et de recommandation de la culture d'ananas
(Ananas comosus (L.) Merr) variété Pain de sucre en zone subéquatoriale du Bénin. Annales de l'Université de Parakou, Série Sciences Naturelles et Agronomie 1: 51-69.

Agbangba CE, Dagbenonbakin GD, Tossou C, Kindomihou MV, 2008. Nutritional status assessment of Pineapple, variety "Smooth cayenne" and "Perola" using the Diagnosis and Recommendation 
Integrated System Method. ISBN: 978999-19-377-8-7. N $^{\circ} 5012$ of 01/24/2011, 1st trimester 2011, National Library of Benin. $10 \mathrm{p}$.

Alongo S, Visser M, Drouet T, Kombele F, Colinet G, Bogaert J, 2013. Effets de la fragmentation des forêts par l'agriculture itinérante sur la dégradation de quelques propriétés physiques d'un Ferralsol échantillonné à Yangambi, R.D. Congo. Tropicultura 31(1): 36-43.

Azontonde HA, 1991. Physical and hydraulic properties of soils in Benin. Soil Water Balance in the Sudano Sahelian Zone (Proceedings of the Niamey Workshop, February 1991). IAHS Publ. no. 199, 1991. $254 \mathrm{p}$.

Barbarick KA and Ippolito JA, 2007. Nutrient assessment of a dryland wheat agroecosystem after 12 years of biosolids applications, Agron. J. 99: 715-722.

Bell DF, 1964. Loss-on-ignition as an estimate of organic matter and organic carbon in noncalcareous soils. Journal of Soil Science 15: 84-92.

Blackshaw RE, Molnar LJ, Larney FJ, 2005. Fertilizer, manure and compost effects on weed growth and competition with winter wheat in western Canada, Crop Prot. 24: 971-980.

Bray RH and Kurtz LT, 1945. Determination of total, organic and available forms of phosphorus in soils. Soil Science 59: 3945.

CeRPA, 2005. Plan de campagne 2005-2006, CeRPA-Atlantique-Littoral, Abomey-Calavi Bénin $78 p+$ Annexes.

Chikae M, Ikeda R, Kerman K, Morita Y, Tamiya E, 2006. Estimation of maturity of compost from food wastes and agro-residues by multiple regression analysis. Bioresource Technology 97: 1979-1985.

Courtney RG and Mullen GJ, 2008. Soil quality and barley growth as influenced by the land application of two compost types. Bioresource Technology 99: 2913-2918.

Decaëns $T$, Lavelle $P$, Jiménez JJ, Escobar $G$, Rippstein G, 1994. Impact of land management on soil macrofauna in the Oriental Llanos of Colombia. Eur. J. Soil Biol. 30: 157-168.

Edwards L, Burney JR, Richter G, MacRae AH, 2000. Evaluation of compost and straw mulching on soil-loss characteristics in erosion plots of potatoes in Prince Edward Island, Canada. Agriculture, Ecosystems and Environment. 81: 217-222.

Evanylo G, Sherony C, Spargo J, Starner D, Brosius M, Haering K, 2008. Soil and water environmental effects of fertilizer, manure and compost-based fertility practices in an organic vegetable cropping system. Agriculture, Ecosystems and Environment 127: 50-58.

FAO (Food and Agriculture Organization), 2009. Statistical databases. Available from http://faostat.fao.org/DesktopDefault.aspx ? PagelD=567\&lang=fr\#ancor. Accessed on 03 March 2015.

Gabhane J, William SPMP, Bidyadhar R, Bhilawe P, Anand D, Vaidya AN, Wate SR, 2012. Additives aided composting of green waste: Effects on organic matter degradation, compost maturity and quality of the finished compost. Bioresource Technology 114: 382-388.

Godefroy J, Py C, Tisseau MA, 1971. Action de la fumure phosphatée en culture d'ananas en Cote d'Ivoire et en Guadeloupe. Fruits 26 (3): 207-210.

Helmke PA and Sparks DL, 1996. Lithium, sodium, potassium, rubidium and cesium. In: Sparks DL (ed.) Methods of soil analysis. Part 3. Chemical methods. SSSA Book Series No. 5. SSSA and ASA, Madison, WI, 551-574 pp.

Helvetas-Bénin, 2008. Appui à la Filière Ananas Biologique et Équitable: Document du Projet Helvetas-Benin. Cotonou $22 \mathrm{p}$.

Hien E, Ganry F, Hien V, Oliver R, 2002. Carbon dynamics in a soil of southwestern Burkina savannah under the effect of the cultivation and farming practices. In: Jamin JY, Seiny Boukar L, Floret C, 2003. (ed.) African Savannahs: The changing spaces, actors face new challenges. Proceedings of the conference, May 2002, Garoua, Cameroon. Prasac, N'Djamena, Chad - CIRAD, Montpellier, France.

Jackson ML, 1968. Chemical soil analysis. Prentice Hall, Inc., Inglewood Cliffs, N.J., $64 \mathrm{p}$.

Kintohou, 2003. Using the unique formula fertilizer on pineapple in Allada's commune. Engineer Agronomist thesis, University of Abomey-calavi, $121 \mathrm{p}$. 
Kjeldahl J, 1883. A new method for the determination of nitrogen in organic matter. Anal. Chem. 22: 366-382.

Kowaljow E and Mazzarino MJ, 2007. Soil restoration in semiarid Patagonia: Chemical and biological response to different compost quality. Soil Biology and Biochemistry 39:1580-1588.

Leroy BLMM, Bommele L, Reheul D, Moens M, De Neve S, 2007. The application of vegetable, fruit and garden waste (VFG) compost in addition to cattle slurry in a silage maize monoculture: Effects on soil fauna and yield, Eur. J. Soil Biol. 43: 91100.

Liu CH, Liu Y, Fan C, Kuang SZ, 2013. The effects of composted pineapple residue return on soil properties and the growth and yield of pineapple. Journal of Soil Science and Plant Nutrition 13(2): 433-444.

Mallory EB and Griffin TS, 2007. Impacts of soil amendment history on nitrogen availability from manure and fertilizer, Soil Sci. Soc. Am. J. 71: 964-973.

Mamoudou T, François L, Frederic A, Badiori O, Korodjouma O, Michel S, 2012. Influence des pratiques agricoles sur la macrofaune du sol: cas de l'enfouissement de la paille et du fumier Int. J. Biol. Chem. Sci. 6(4): 1761-1773.

Mangara A, N'daAdopo AA, Traore K, Kehe M, Soro K, Toure M, 2010. Etude phytoécologique des adventices en cultures d'ananas. Journal of Applied Biosciences 36: 2367- 2382.

Meng L, Ding W, Cai Z, 2005. Long-term application of organic manure and nitrogen fertilizer on $\mathrm{N} 2 \mathrm{O}$ emissions, soil quality and crop production in a sandy loam soil, Soil Biol. Biochem. 37: 20372045.

Metson AJ, 1956. Methods of chemical analysis for soil survey samples. $\mathrm{N} Z$ Soil Bur Bull $\mathrm{n}^{\circ}$ 12.

Parmelee RW, Beare MH, Cheng W, Hendrix PF, Rider SJ, Crossley JRDA, Coleman DC, 1990. Earthworms and enchytraeids in 15 conventional and no-tillage agroecosystems: a biocide approach to assess their role in organic matter breakdown. Biol. Fertil. Soils 10: 1-10.

Py A, Lacoeuilhe JJ, Teisson C, 1965. L'ananas, sa culture et ses produits Moisonneuve et Larose. $39 \mathrm{p}$.
$\mathrm{R}$ Core Team, 2015. R: A language and environment for statistical computing. $R$ Foundation for Statistical Computing, Vienna, Austria. URL http://www.Rproject.org/.

Robinson GW, 1949. Soils. Their origin, constitution and classification. London. Thomas Murby and Co N.Y.J., Wiley and Sons Inc. $573 p$.

Shaver TM, Peterson GA, Sherrod LA, 2003. Cropping intensification in dryland systems improves soil physical properties: Regression relations. Geoderma 116:149164.

Sodhi GPS, Beri V, Benbi DK, 2009. Soil aggregation and distribution of carbon and nitrogen in different fractions under longterm application of compost in rice-wheat system Soil Till. Res. 103(2): 412-418. DOI 10.1016/j.still.2008.12.005.

Sommer R, Ryan J, Masri S, Singh M, Diekmann $J$, 2011. Effect of shallow tillage, moldboard plowing, straw management and compost addition on soil organic matter and nitrogen in a dryland barley/wheat-vetch rotation. Soil and Tillage Research 115-116: 39-46.

Sossa EL, Amadji GL, Vissoh PV, Hounsou BM, Agbossou KE, Hounhouigan DJ, 2014. Caractérisation des systèmes de culture d'ananas (Ananas comosus (L.) Merrill) sur le plateau d'Allada au Sud-Bénin. Internationnal Journal of Biological and Chemical Sciences 8(3): 1030-1038.

Tossou C, 2001. Impact de la culture de l'ananas sur l'environnement dans le département de I'Atlantique (République du Bénin). Mémoire de fin de cycle pour l'obtention du Diplôme d'Etudes supérieures Spécialisées en Aménagement et Gestion des Ressources Naturelles. FSA-UNB, $109 \mathrm{p}$.

Wei X, Hao M, Shao M, Gale WJ, 2006. Change in soil properties and availability of soil micronutrients after 18 years of cropping and fertilization. Soil Till. Res. 91: 1-2, 120-130.

Whalen JK and Chang C, 2002. Macroaggregate characteristics in cultivated soils after 25 annual manure applications, Soil Sci. Soc. Am. J. 66: 1637-1647.

Yemefack M, Nounamo L, Rosaline N, Bilong P, 2004. Influence des pratiques agricoles sur la teneur en argile et autres propriétés 
Sossa et al. J. Appl. Biosci. Change in a ferralsol physico-chemical properties under pineapple cropping system in southern of Benin

agronomiques d'un sol ferrallitique au sud Cameroun. TROPICULTURA 22 (1): 3-10.

Zougmore R, Ouattara K, Mando A, Ouattara B, 2004. Rôle des nutriments dans le succès des techniques de conservation des eaux et des sols (cordons pierreux, bandes enherbées, zaï et demi-lune) au Burkina Faso. Sécheresse 15: 41-48. 